\title{
Ariosto in English
}

\section{Julius A. Molinaro}

The celebrations held in 1974 in Italy and abroad to commemorate the fifth centenary of his birth have served to draw attention to the life and works of Ludovico Ariosto. In the following pages a discussion of three aspects of his work will revolve around Ariosto for the reader of English.

Barbara Reynolds' long introduction of 113 pages to her verse rendering of the Orlando Furioso requires no justification as there are few readers who can afford to dispense with assistance in reading a work of this magnitude. ${ }^{1}$ Few scholars will argue with her premise that "Ariosto is the poet of Europe" as Virgil is of Rome. No one is likely to challenge her statement that Ariosto's chief purpose was to give delight and that the Orlando Furioso "is above all a poem to be enjoyed." Her introduction, based on a valid assumption, is most useful and one to which the reader will likely return for reference on more than one occasion. In it he will find information on the literary origins of the poem, an historical account of the Carolingian and Arthurian cycles, a discussion of classical influences on the Orlando Furioso and a section on Ariosto and his times. In this way Barbara Reynolds attempts to bridge the gap separating us from the poem itself and does for the English reader what Zingarelli has already done so successfully for the Italian. ${ }^{2}$ Her examination of the relationship between the Orlando Furioso and English literature, beginning with Marlowe's introduction of the story of Isabella's death in Tamburlaine in 1590 and ending with the twentieth-century, follows the changing fortunes of that work from enthusiastic to indifferent (evident in a statement by D.S. Carne-Ross that no eminent English contemporary writer or critic has been attracted to him.) The translator's hope that her version will arouse the general reader's interest in a poet who has undeservedly been neglected for some time will be shared by all those who appreciate Ariosto as a pivotal figure in Renaissance Italy.

Section five of her introduction, dealing with the translation and its predecessors, examines the main features of some of the English versions of the Orlando Furioso. The translator reserves special 
praise for Harington's version of 1591, whose charming archaic quality she admires, but whose insensitivity to female beauty she decries. She says nothing of William Huggins' version of 1757 in octaves, nor of Henry Boyd's of 1784, but agrees with Scott's scornful description of John Hoole's couplets of 1783 as "the noble transmuter of the gold of Ariosto into lead" (p. 92). William Stewart Rose's translation she characterizes as accurate but "flat and lifeless" (p. 92), a charge probably unacceptable to A. Bartlett Giamatti and Stewart Baker, who in 1968 brought out a handsome paperback edition of this version for The Bobbs-Merrill Company. For Giamatti and Baker, the Rose translation, despite its excessive accuracy and occasional obscurities, preserves much of "the speed and unemphatic ironic wit of Ariosto's original" and is "by far the best verse translation" (p. xlvii).

Barbara Reynolds prefers verse too, arguing that the Italian hendecasyllable can be rendered perfectly by the five-foot heroic line, as her translation of the Orlando Furioso demonstrates in a variety of ways. Twentieth-century English, the translator contends, is eminently suitable for rendering the long passages of the idiomatic and conversational language of the Orlando Furioso, and others, which are unrhetorical and realistic in character. English with its twin Anglo-Saxon and Latin tradition offers a range and flexibility of language equal to the demands of translating Ariosto's Italian. Barbara Reynolds makes liberal use of assonance and impure rhymes, which abound in English, and upholds the validity of the rhymed couplet.

Supporting Barbara Reynolds' poetic talent is her considerable linguistic background of long standing. She published a book on The Linguistic Writings of Alessandro Manzoni: A Textual and Chronological Reconstruction in Cambridge in 1950, and acted as general editor of the Italian-English section, Volume 1, of The Cambridge Italian Dictionary, printed in 1962. For this volume she was also responsible for archaic and dialect terms. Consider in this regard Canto X, octaves 75 to 91 , where Ariosto has Ruggiero witness a parade of English, Scottish and Irish armies, reviewed by Rinaldo, who, in order to seek reinforcements for the beleaguered Charlemagne in Paris, had gone to England. There a stranger identifies for Ruggiero a number of nobles at the head of their troops and the event gives Ariosto the opportunity of describing in some detail their individual coats of arms. This passage of the translation is one example of the quality of scholarship brought to bear on this most recent English translation of the Orlando Furioso, for Barbara Reynolds has here sought to render Ariosto's descriptions of the escutcheon of each noble with precise heraldic terminology. For 
further clarification she includes in her notes, which are very full indeed, four reproductions of the armorial bearings of the Dukes of Lancaster and Norfolk, as well as those of the Earls of Essex and the crest of Berkeley. As the notes point out, Ariosto's knowledge of heraldry was not at all infallible as he often misunderstands coats of arms or else freely invents them with little concern for accuracy.

The translation adheres as closely as possible to the original, in contemporary language, taking the liberties that it reasonably must for the sake of rhyme. It is not at all forced or stilted but strives to conform to the varied tones and levels of the narrative, conveying the irony of Ariosto's commentary on chivalry beginning with the line: "O noble chivalry of knights of yore!" (I.22); or the seriousness of the exordium on the unexpected changes in man's life:

No man can know by whom he's truly loved When high on Fortune's wheel he sits, serene. His friends surround him, true and false, unproved, And the same loyalty in all is seen. (XIX.1)

Whether the realistic flavor of the original is preserved as in the following homeric simile each reader will decide for himself:

As when a log of wood, which once was green,

Of which the pith has shrivelled, leaving spaces

Where sappy softness formerly has been,

Is thrown upon the flames whose warm embraces

Convert to roars and groans the air within,

As through the hollow aperture it races,

So does that injured myrtle moan and shriek,

As through the splitting bark it tries to speak. (VI.27)

Orlando's realization that he has lost Angelica to Medoro is brought out in all its pathos:

A hundred times the lovers' names are seen,

'Angelica,' 'Medoro,' intertwined.

Each letter is a knife which, sharp and keen,

Pierces his bleeding heart; his tortured mind. (XXIII.103)

Professor Reynolds has not only provided the reader with a substantial introduction to the Orlando Furioso but also with an index of proper names plus tables of the principal warriors, Christian and pagan, and of horses, chief weapons, their owners and other useful reference lists. Genealogical tables, maps of 
journeys, a drawing of the battlefield around Paris, help refresh one's memory when necessary. The running titles given on each page serve as summaries of each canto, indispensable in a work as vast as the Orlando Furioso. Fidelity to the original text is clearly a high priority for the translator but her principal aim appears to be that Ariosto's poetry, on which she lavishes much affection, should ring true in English. The sensual passages are not pruned as they were by John Hoole's version of 1783 but handled realistically. The result of the translator's labors is a lively version, the fruit of a fine critical taste and a sensitivity to poetry.

Turning from poetry to prose, Robert Griffin's volume on Ariosto, ${ }^{3}$ together with C.P. Brand's on the same subject, published by the Edinburgh University Press in 1974, will earn the gratitude of readers who up to the present have only had available to them, in English, Edmund Gardner's The King of Court Poets: A Study of the Works, Life and Times of Ludovico Ariosto, which came out in London in 1906 and is now outdated from many points of view. Griffin's book concentrates on the Orlando Furioso and so he disposes of the life and times of Ariosto in the first chapter, the minor works in the second, leaving five for his principal concern, the poem itself. Griffin strives to present a synthesis of Ariosto scholarship and competently discusses in Chapter 3 the theme of chivalry against the background of the Carolingian and Arthurian cycles in French and Italian literature. In the process of doing so, Griffin seems to be excessively harsh in his censure of Pio Rajna, whose study of the sources of the Orlando Furioso is unique and one of the most reliable books of its kind." To say that this very meticulous scholars "concluded that the Furioso was a degeneration of medieval romance and implied that Ariosto's originality was inversely proportional to the number of his sources as though creativity could be quantified" (p. 58) is an overstatement which ignores Pio Rajna's basic premise. Rajna, who calls the Furioso an immortale poema (p. 3), an opera d'arte (p. 36), does not deny Ariosto's originality. In Rajna's opinion, the Orlando Furioso continues the Innamorato in subject matter only and, while Ariosto may use the invention of the Innamorato, the disposition of the material is his own. In saying that the Furioso is a metamorphosis of the old, Pio Rajna could not have chosen a more fitting word to apply to the art of that poem. The appropriation of the material of the Innamorato does not detract from Ariosto's merit, a point Pio Rajna makes unmistakeably clear (p. 609). Lanfranco Caretti's definition of Le fonti dell'Orlando Furioso as a monument of historical research which deserves to be reprinted because of its unsurpassed usefulness is supported by many contemporary Renaissance scholars. ${ }^{5}$ 
Griffin properly begins in Chapter 4 his discussion of variety in the Orlando Furioso with a short account of the critical reaction following its publication in the second half of the sixteenth century which made an easy target of Ariosto, whom critics charged with breaching Aristotle's rules on the epic poem.

Griffin presents the sixteenth-century arguments for and against Ariosto's new concept of the epic poem, a radical departure from its old classical forms embracing a broad vision of reality. His analysis of Ariosto's metaphor of the journey of life, la strada, the aimless wandering of the knights through forests and man's inability to steer a clear course, illustrates the richness and complexity of the theme.

In Chapter 5 Griffin takes up the implications of Astolfo's journey to the earthly paradise which he associates with the quest motif and the Renaissance interest in navigation and exploration. At the end of the chapter Griffin devotes a few pages to the episode of Rinaldo and the wine goblet. It will be recalled that failure to drink from the wine goblet without spilling it was proof that a man's wife was unfaithful. According to Griffin, Rinaldo's refusal to take the test was proof that he now possessed secure selfknowledge and an awareness of the limits of human aspirations. As Mario Santoro has pointed out, the "prudent" Rinaldo, like Orlando, has through experience acquired perfect control of his powers of reason. The episode constitutes an exemplary lesson in tolerance and moderation. ${ }^{\circ}$

Whether one agrees or not with Griffin's handling of irony in Chapter 6, which grapples with a fundamental problem in the Orlando Furioso, there is little doubt that it is one of the most complex to deal with but also one of the most rewarding in the book. Ariosto's use of irony, parody and caricature here receives thoughtful attention.

Concluding with a chapter on the history of Ariosto criticism, Griffin in passing writes a page on the vogue of the Orlando Furioso in England. Aside from the poem's impact on the Faiërie Queene, the history of Ariosto in England is more a matter of presence than genuine influence (p. 154). While Griffin's book brings together the results of recent investigations by other scholars on the same subject, a number of his own original observations make it of particular value to the literature on Ariosto in English.

The Comedies of Ariosto, for the first time presented in English, are of considerable interest for their intrinsic merit, as Beame and Sbrocchi, the editors and translators, maintain.? Ariosto's plays are usually interpreted in the light of his debt to Plautus and Terence and of his contribution to Italian Renaissance theater and only 
incidentally in their relationship to the Orlando Furioso, a subject to which there are many brief allusions. The following observations are designed to indicate areas which might be further explored.

La Cassaria, written in 1507, and performed at the Court of Ferrara the following year, displays a familiar interest in contemporary life. Ariosto, as we know from the Orlando Furioso, ${ }^{8}$ was an admirer of his age, refusing to set the accomplishments of the ancients above those of his own times. In the prologue of $L a$ Cassaria, we read that "today's talents are not so different from those of the past." Crisobolo, father of the rash young man in love, is the same authoritarian type of parent as Amone, Bradamente's father. The satirical intent of some scenes, such as Act V, Scene 3, directed against women, takes on a less sharp and more mellow tone in the Orlando Furioso, where a more balanced view of men's foibles is the rule. A fast-moving plot is clear evidence of an ability which comes to full maturity in his major work.

I Suppositi, which owes so much to classical comedy and had its premiere 6 February 1509, has elements of realism, an essential quality of the Orlando Furioso. It was the first Italian play to be translated into English. While the figures of the parasite and the pedant, a doctor of laws, quick to quote Latin, may have been suitable characters for comedy, Ariosto may have decided that they were too stereotyped for inclusion in the Orlando Furioso. The love story of the play may have given him some insight into this emotion which plays such a conspicuous part in the poem. The figure of the old man in love, a familiar character in sixteenthcentury comedy, disappears in that role to re-appear in the guise of the lascivious hermit who unsuccessfully tries to make love to Angelica. The play does not lack satire directed against the law courts which present endless obstacles to those who have only right on their side (Act IV, Scene 8). Ariosto injects humour into the play in which the servant disguised as his master distinguishes himself as an excellent scholar.

Il Negromante, begun in 1510 , left unfinished until 1520, but not publicly presented until 1529, centers around the figure of a magician who takes advantage of the fools around him who believe in his supernatural powers. The subject of the play, man's folly, "la sciocchezza, che al mondo è in abondanzia" ("stupidity which abounds in the world"), is a target not forgotten in the Orlando Furioso, where Ariosto censures those who lose themselves in magiche sciocchezze (XXXIV.85). It is interesting that Camillo Pocosale, one of the stupidest characters of the play, should be the one to aim a stinging attack against "rapacious notaries" who use every kind of legal documents to steal from the public. Ariosto uses 
the words carte (legal documents), libelli (writs), citatorie (judicial citations) and essamine (public testimonies) not only in Il Negromante but in the Orlando Furioso as well. The similarity in language and thought is striking. Animal imagery which Ariosto uses extensively in the Orlando Furioso finds a place in the play. Government and other public officials when they assume office put aside their human features and take on those of animals, of the wolf, the fox or birds of prey (Act 1, Scene 3). The type of parallel the necromancer draws in Act II, Scene 2, between men and animals is of the same quality as the kind of metaphor Ariosto employs so freely in the Orlando Furioso.

If, as has been asserted, Ariosto's plays are more important for historical rather than artistic reasons, La Lena, performed in 1528 at the court of Ferrara, would serve as ample justification. Composed after he had published two editions of the Orlando Furioso and while he was preparing the third, during a peak period of literary achievement, La Lena remains a surface treatment of Renaissace corruption. Ariosto was obviously satisfied to give his audience a cynical picture of society, where corruption was rampant in the law courts and in the law enforcement agencies. Ariosto introduces potentially powerful themes which he does not develop. The figure of the go-between, for example, the principal character of the play, lacks depth, as do others of equal importance.

Also included in The Comedies of Ariosto are the revised version of La Cassaria, performed in 1531, and I Studenti, left unfinished by Ludovico, retitled La Scolastica, and completed by Gabriele, his brother, between 1543 and 1547. Beame and Sbrocchi in their introduction, supported by abundant notes, have placed the plays in their proper historical setting and reminded readers that they merit consideration as works of distinction and innovation.

Writings on Ariosto in English, though relatively few in number when compared with those which have appeared in Italy during the centenary, are of a quality worthy of serious attention.

\section{University of Toronto}

\section{NOTES}

1 Orlando Furioso (The Frenzy of Orlando), A Romantic Epic by Ludovico Ariosto, 2 Parts, translated with an introduction by Barbara Reynolds, Baltimore: Penguin Books, 1975, 1977 pp. 827, 794.

2 Orlando Furioso di Ludovico Ariosto, ed. Nicola Zingarelli (Milano, 1959), pp. ixlxxv.

3 Robert Griffin, Ludovico Ariosto New York: Twayne Publishers, Inc., 1974, pp. 180.

4 Pio Rajna, Le fonti dell' Orlando Furioso (Firenze, 1900). 
5 Lanfranco Caretti, Ariosto e Tasso (Torino, 1961), p. 28, "quel 'monumento' di ricerca storica ...troppo a torto declassato a mero repertorio erudito e che forse varrebbe la pena di ristampare per la sua ancora non superata utilità."

6 Mario Santoro, "La prova del nappo e la cognizione ariostesca del reale," Esperienze letterarie 1 (1976), 20, "una esemplare lezione di tolleranza, di moderazione, di misura, a specchio della cognizione della condizione umana."

7 The Comedies of Ariosto, translated and edited by Edmond M. Beame and Leonard G. Sbrocchi, Chicago: The University of Chicago Press, 1975, pp. xlv, 322.

8 Carlo Grabher, Sul teatro dell'Ariosto. (Roma, 1946). This does not deal with Orlando Furioso. See also Walter Binni, "L'esperienza teatrale," in Metodo e poesia di Ludovico Ariosto (Messina, 1947), pp. 44-70. 